\title{
Colorectal Cancer: a dedicated journal for a fast-moving field
}

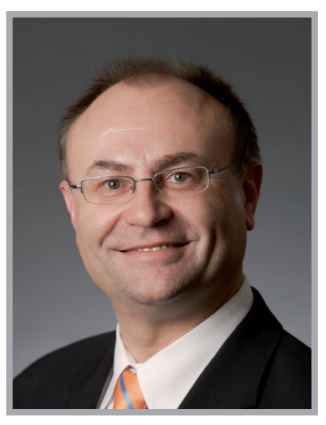

Heinz-Josef Lenz*: Senior Editor

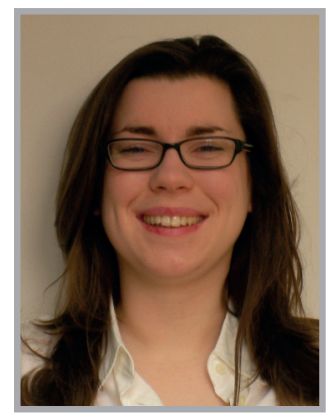

Charlotte Barker: Launch Editor

\author{
"With the incidence of colorectal \\ cancer increasing and so many new \\ treatment strategies under investigation, \\ we feel that the time is right for a \\ journal tailored especially to the needs \\ of clinicians and other health workers \\ in the field of colorectal \\ cancer management."
}

We would like to welcome you to this inaugural issue of our new journal Colorectal Cancer. With the incidence of colorectal cancer increasing and so many new treatment strategies under investigation, we feel that the time is right for a journal tailored especially to the needs of clinicians and other health workers in the field of colorectal cancer management.

Colorectal Cancer covers new and established diagnostic and treatment options for an international audience. The journal aims to provide clinicians with the essential information they need in this increasingly complex field; for example, integrating molecular markers and genetic signatures into clinical practice. Each issue will feature concise, accessible reviews by leading experts in the field, ideal for busy doctors. In each Review, Practice Points will highlight the key points for clinicians to bear in mind in their day-to-day practice. In addition, each issue will include a range of Editorials and Perspectives, giving expert insight into areas of debate or controversy.
The Journal Watch section will provide highlights from the literature, collated and put into context by our expert panel. Leading experts will give their opinion on emerging treatment options and share their wealth of experience in topical Interviews and the Ask the Expert feature.

This first issue provides a great example of the range and quality of content that the journal will feature. Leading experts discuss areas from screening to surgical techniques, address controversy and look ahead to potential future treatment options. While Heriot and colleagues reveal what we can learn from the past in abdominoperineal excision surgery [1], Vallböhmer et al. look to the future to emerging markers in response prediction [2]. An interview with Professor Lars Påhlman discusses his 30-year career in colorectal cancer and why he feels that quality control is the key to improving outcomes [3]. We also Ask the Expert, Robert Benamouzig, about the evidence for aspirin as chemoprevention for colorectal cancer [4]. Topical Editorials

Unitec House, 2 Albert Place, N3 1QB, London, UK; c.barker@futuremedicine.com

*Author for correspondence: 1441 Eastlake Avenue, Suite 3456, CA, USA; Tel.: +1 323865 3955; lenz@hsc.usc.edu 
tackle the controversy surrounding laparoscopicassisted surgery and speculate on the potential of cancer stem cells as a target for future therapies $[5,6]$. We would like to thank all the contributors to this launch issue.

We would also like to thank the Editorial Board of the journal, many of whom have already contributed to the first issues of the journal. We are truly delighted to have so many of the key opinion leaders in the field represented here and we look forward to working with them to guide the content and development of the title. We hope that you, the reader, will also help to guide the direction of the journal by letting us know what topics and articles are of most value to you. We welcome unsolicited submission of Reviews, Perspectives and Original Research Articles.

Colorectal Cancer is published by Future Medicine Ltd (London, UK), renowned for its collection of journals providing healthcare practitioners and research professionals with a unique source of objective, cutting-edge information on exciting trends emerging in light of advances in medicine, healthcare and clinical practice. All aspects of commissioning and production of the journal are carried out by our dedicated team, ensuring excellent quality of content and clear, attractive presentation. All Reviews, Perspectives and Original Research Articles undergo rigorous double-blind peer review by independent experts to ensure high-quality, accurate information. We offer fast publication (8-12 weeks from submission to publication) with no publication fees or page charges. The editorial team will guide authors through submission and peer review, providing regular updates on the manuscript.

We would like to conclude by thanking everyone who has contributed to the launch of this exciting new publication. We hope that you will continue to enjoy the concise, readable overview of current and forthcoming management options provided in this and future issues of Colorectal Cancer.

\section{Financial \& competing interests disclosure}

The authors have no relevant affiliations or financial involvement with any organization or entity with a financial interest in or financial conflict with the subject matter or materials discussed in the manuscript. This includes employment, consultancies, honoraria, stock ownership or options, expert testimony, grants or patents received or pending, or royalties.

No writing assistance was utilized in the production of this manuscript.

\section{References}

1 Wallace WD, White TJ, Lynch AC, Heriot AG. A century of abdominoperineal excision for rectal cancer. Colorect. Cancer 1(1), 25-35 (2012).

2 Vallböhmer D, Krieg A, Stoecklein NH, Knoefel WT. Response prediction in the multimodality therapy of locally advanced rectal cancer. Colorect. Cancer 1(1), 49-55 (2012).

3 Påhlman L. Future of colorectal surgery. Colorect. Cancer 1(1), 21-23 (2012).

4 Benamouzig R. Aspirin for colorectal cancer chemoprophylaxis. Colorect. Cancer 1(1), 17-19 (2012).
5 Kennedy GD. Should laparoscopic-assisted proctectomy be the standard of care for patients with resectable rectal cancer? Colorect. Cancer 1(1), 3-6 (2012).

6 Jawad N, Wright N. Stem cells: a potential target in colorectal cancer? Colorect. Cancer 1(1), 7-9 (2012). 